\title{
Peran Puerarin terhadap Aktivitas Intra dan Ekstraseluler pada Kultur Human Umbilical Vein Endothelial Cells (HUVECs) Pasca Induksi Leptin
}

\author{
M. Sasmito Djati ${ }^{1}$, Satuman ${ }^{2}$, Retty Ratnawati ${ }^{2}$, Sri Widyarti ${ }^{1}$, Erly Nur Aisyah ${ }^{1}$, \\ Noer Hasanah ${ }^{1}$, Eko Puji Astuti ${ }^{1}$, Ririn Rochmawati ${ }^{1}$ \\ ${ }^{1}$ Jurusan Biologi, Fakultas Matematika dan Ilmu Pengetahuan Alam, Universitas Brawijaya, Malang \\ ${ }^{2}$ Fakultas Kedokteran Universitas Brawijaya, Malang
}

\begin{abstract}
Abstrak
Beberapa penelitian terkini menyebutkan bahwa leptin merupakan salah satu penyebab disfungsi endotel yang merupakan salah satu penyebab aterogenesis. Antioksidan puerarin diduga memiliki kemampuan untuk mencegah mekanisme aterogenesis yang distimulasi oleh beberapa sitokin. Berdasarkan hal tersebut, maka tujuan penelitian ini adalah membuktikan dan mengetahui potensi puerarin untuk menghambat ekspresi dan aktivitas intra dan ekstraseluler VCAM-1, PPAR- $\gamma$, SOD dan $\mathrm{H}_{2} \mathrm{O}_{2}$, apoptosis dan nekrosis pada kultur Human Umbilical Vein Endothelial Cells (HUVECs) yang diinduksi $25 \mathrm{ng} \mathrm{ml}^{-1}$ leptin. Penelitian ini mempergunakan sel kultur primer HUVECs yang dibagi menjadi empat kelompok perlakuan, yaitu kelompok $0 \mathrm{ng} \mathrm{ml}^{-1}$ dan $0 \mu \mathrm{M}$ puerarin, kelompok sel yang diinduksi 25 $\mathrm{ng} \mathrm{m}{ }^{-1}$ leptin selama 12 jam, kelompok induksi puerarin 5, 25, 200 dan $525 \mu \mathrm{M}$ puerarin selama enam jam tanpa leptin, kelompok induksi leptin dan puerarin dengan konsentrasi 5, 25, 200 dan $525 \mu \mathrm{M}$ selama enam jam. Aktivitas VCAM-1 dan PPAR- $\gamma$ diketahui dengan analisis imunositokimia, metode ELISA digunakan untuk analisis aktivitas SOD dan $\mathrm{H}_{2} \mathrm{O}_{2}$. Apoptosis dan nekrosis sel dianalisis setelah HUVECs diberi penanda BrdU selama $20 \mathrm{jam}$. Data dianalisis dengan analisis satu jalur (ANOVA) dan dilanjutkan dengan uji Tukey. Hasil penelitian menunjukkan bahwa induksi $25 \mathrm{ng} \mathrm{ml}^{-1}$ dapat meningkatkan ekspresi VCAM-1 $(2,68 \pm 0,15) \%$ dibandingkan dengan perlakuan $0 \mathrm{ng} \mathrm{ml}^{-1}(0,54 \pm 0,15) \%$. Perlakuan induksi puerarin 5, 25, 200, $525 \mu \mathrm{M}$ memberikan dampak negatif terhadap ekspresi VCAM-1 meskipun pengaruh ini tidak signifikan. Puerarin dapat menekan apoptosis dan nekrosis sel, $525 \mu \mathrm{M}$ puerarin secara efektif dapat menekan ekspresi PPAR- $\gamma$. Puerarin tidak memberikan dampak yang signifikan terhadap aktivitas ekstraseluler berdasarkan hasil analisis aktivitas SOD dan $\mathrm{H}_{2} \mathrm{O}_{2}$.
\end{abstract}

Kata kunci: apoptosis, $\mathrm{H}_{2} \mathrm{O}_{2}$, HUVECs, nekrosis, leptin, puerarin, VCAM-1, PPAR- $\gamma$, SOD

\section{PENDAHULUAN}

Obesitas merupakan penimbunan lemak dalam jumlah besar yang akan menimbulkan berat tubuh yang berlebihan (overweight) [1]. Obesitas merupakan faktor resiko terjadinya diabetes, hipertensi dan aterosklerosis [2].

Aterosklerosis adalah keadaan arteri yang dicirikan oleh penebalan bagian dinding pembuluh arteri yang berdekatan dengan lumen dengan sejumlah sel otot polos abnormal, makrofag, limfosit, berkumpulnya kolesterol dan zat lemak lainnya pada sel ini secara ekstraselular dan penebalan lapisan matrik jaringan konektif [1]. Aterosklerosis terjadi karena kerusakan pada sel endotel (disfungsi endotel) vaskular. Kerusakan ini disebabkan oleh gangguan mekanik, biokimia dan inflamasi $[3,4]$.

\footnotetext{
Alamat korespondensi:

M. Sasmito Djati

E-mail : msdjati@yahoo.co.id

Alamat : Jurusan Biologi, Fakultas Matematika dan IImu Pengetahuan Alam, Universitas Brawijaya, Jl. Veteran, Malang
}

Penderita obesitas memiliki kadar plasma leptin yang tinggi dalam darah yang disebabkan oleh penumpukan sel adiposit penghasil leptin. Jaringan adiposit bertindak sebagai sumber mediator proinflamasi seperti TNF- $\alpha$, IL-6, leptin, resisten dan C-reactive protein (CRP), yang dapat menginduksi terjadinya disfungsi endotel, resistansi insulin dan akhirnya aterosklerosis [2]. Menurut Singh et al., tingkat leptin yang tinggi juga dapat meningkatkan kadar C-reactive protein (CRP) [5]. Selanjutnya CRP dapat menginduksi ekspresi vascular cellular adhesion molecule-1 (VCAM-1) melalui jalur sinyal NF-KB dalam HUVECs $[6,7]$.

Puerarin merupakan senyawa isoflavon yang bersifat antiinflamasi. Puerarin dapat mencegah disfungsi endotel yang diinduksi oleh banyak faktor [8]. Di dalam pembuluh darah sel endotel membentuk barier yang selektif dalam usaha mencegah transfer berbagai substansi yang ada dalam sistem pembuluh darah [9]. Sel endotel menyokong regulasi tekanan darah dan aliran darah dengan melepaskan vasodilatator nitric oxide (NO) dan prostacyclin (PGI2) dan vaso- 
kontriktor endothelin (ET) dan platelet activatory factor [10]. Menurut Sanyin et al., puerarin dapat menginduksi ekspresi eNOS. Endothelial nitric oxide synthase dapat meng-hasilkan endogenous vasodilator nitric oxide (NO) [11]. NO (nitric oxide) bersifat menahan aktivasi inflamasi pada sel endotel, misalnya menurunkan ekspresi VCAM-1 dengan mening-katkan produksi penghambat faktor transkripsi intraseluler NF-кB (ІкB $\alpha)$ [3].

Namun belum diketahui apakah pemberian puerarin dalam jangka pendek berpengaruh terhadap disfungsi endotel. Oleh karena itu, kajian pada studi ini adalah pengujian pengaruh puerarin terhadap ekspresi intra seluler VCAM-1, PPAR- $\gamma$, dan aktifitas ekstraseluler SOD dan $\mathrm{H}_{2} \mathrm{O}_{2}$, apoptosis serta nekrosis pada kultur sel endotel (HUVECs) yang diinduksi leptin.

\section{METODE PENELITIAN}

\section{Isolasi dan Kultur Sel Endotel}

Metode yang digunakan ini menurut Khotimah [12]. Umbilikus dalam cord solution diperoleh dari Rumah Bersalin di Malang, melalui persalinan Caesar. Umbilikus dibersih-kan dengan tisu yang telah dibasahi dengan alkohol $70 \%$. Canul dimasukkan pada salah ujung vena $( \pm$ $1 \mathrm{~cm})$, kemudian diikat dengan benang. Vena umbilikus dibersihkan dengan mengalirkan $10 \mathrm{ml}$ PBSA untuk menghilangkan sisa darah dari jaringan, kemudian ujung umbilikus yang lain disumbat dengan klem dan $5 \mathrm{ml}$ collagenase dimasukkan melalui canul yang dipasang. Selanjutnya umbilikus dihangatkan dengan cara didekap dengan kedua tangan selama tujuh menit. Collagenase yang telah mengandung endotel dikeluarkan dari umbilikus kemudian dimasukkan dalam tabung sentrifugasi steril 15 $\mathrm{ml}$. Umbilikus dibilas dengan $8 \mathrm{ml}$ larutan PBSA untuk membilas sel endotel yang masih tersisa dan ditambahkan ketabung sentrifugasi yang berisi larutan collagense lalu disentrifugasi dengan kecepatan $1000 \mathrm{rpm}$ selama 8 menit. Selanjutnya pelet yang diperoleh diresuspensi dengan medium kultur (TCM 199-sigma) sebanyak $4 \mathrm{ml}$, kemudian ditransfer ke 24 well culture plate yang sebelumnya telah dilapisi gelatin $0,2 \%$ kemudian dimasukkan dalam inkubator $\mathrm{CO}_{2} 5 \%$ pada suhu $37{ }^{\circ} \mathrm{C}$ selama 30 menit. Culture plate diamati di bawah mikroskop, jika sel sudah menempel pada dasar plate, medium kultur diambil dan sel dibilas dengan 3 $\mathrm{ml}$ larutan serum free media dan ditambahkan medium baru. Selanjutnya plate dimasukkan dalam inkubator sampai terbentuk monolayer kurang lebih 3-4 hari dan setiap dua hari sekali dicuci dengan serum free media serta ditambahkan medium baru.

\section{Perlakuan Induksi Leptin pada HUVECs}

Kultur sel yang telah confluent dicuci dengan serum free media dan ditambahkan medium baru. Kemudian, dipapar leptin dengan konsentrasi leptin yang digunakan $0 \mathrm{ng} \mathrm{ml}^{-1}$ dan $25 \mathrm{ng} \mathrm{ml}^{-1}$. Leptin yang telah tersedia dicampur dengan media lengkap. Masing-masing well diisi dengan $500 \mu \mathrm{l}$ kemudian sel endotel diinkubasi $37^{\circ} \mathrm{C}$ selama enam jam.

\section{Perlakuan Puerarin}

Setelah diinkubasi leptin, sel dicuci dan diperlakukan dengan puerarin hasil ekstraksi. Senyawa puerarin didapatkan dari ChemExper. Kadar puerarin terdiri dari lima konsentrasi yaitu 0 (kontrol), $5 \mu \mathrm{M}, 25 \mu \mathrm{M}, 200 \mu \mathrm{M}$ dan $525 \mu \mathrm{M}$. Sel diinkubasi pada $37^{\circ} \mathrm{C}, 5 \% \quad \mathrm{CO}_{2}$ dan kelembaban udara $95 \%$ selama enam jam.

\section{Identifikasi protein VCAM-1 Menggunakan Imunositokimia}

Kultur endotel dicuci dengan PBS (Sigma) $\mathrm{pH}$ 7,4 tiga kali, kemudian difiksasi dengan metanol absolut $10 \%$ dalam PBS pH 7,4 selama 20 menit. Sel dicuci dengan PBS $\mathrm{pH} 7,4$ sebanyak tiga kali masing-masing lima menit. Sel ditetesi dengan 0,02\% sodium azide. Sel dicuci dengan PBS $\mathrm{pH} 7,4$ tiga kali selama lima menit. Sel ditetesi dengan larutan $\mathrm{H}_{2} \mathrm{O}_{2}$ dalam PBS selama 10 menit. Sel ditetesi dengan blocking serum 5\% FBS yang mengandung Triton-X 0,25\% selama satu jam. Sel dicuci dengan PBS. Inkubasi antibodi primer dalam serum 1:200 selama 24 jam. Sel disimpan pada suhu $4{ }^{\circ} \mathrm{C}$. Sel dikeluarkan pada suhu ruang selama 15 menit. Sel dicuci dengan PBS tiga kali masing-masing selama 5 menit. Sel diinkubasi dengan antibodi sekunder 1:400 selama satu jam pada suhu ruang. Sel dicuci dengan PBS tiga kali selama masing-masing lima menit. Sel ditetesi dengan SA-HRP selama 40 menit, dicuci dengan PBS tiga kali selama masing-masing lima menit. Sel ditetesi dengan kromogen DAB (3,3 Diaminobenzedine tetrahydrocloride). Sel ditetesi dengan counterstains dengan hematoxilen selama 10 menit. Sel dicuci dengan air mengalir kemudian akuades selama 10 menit. Sel dibiarkan pada suhu kamar. Jaringan diletakkan pada object glass dan ditetesi dengan entelan.

\section{Pengukuran ELISA dan Fotometrik Coating Microplates (MP)}

Langkah awal dalam pengukuran apoptosis dan nekrosis dengan metode ELISA adalah 
menentukan jumlah well yang digunakan pada microplates. Sebelumnya dilakukan coating microplates yaitu dipipet $100 \mu \mathrm{l}$ anti-DNA coating solution (solution 3) ke dalam well yang telah ditentukan, dan diinkubasi pada suhu $37^{\circ} \mathrm{C}$ selama satu jam. Kemudian coating solution dalam masing-masing well dibuang dengan cara aspirasi atau inverting.

\section{Prosedur Blocking}

Microplates yang telah dicoating, ditambah $200 \mu \mathrm{l} 1 \mathrm{x}$ incubation solution (solution 5), MP ditutup dengan adhesive cover foil dan diinkubasi pada suhu $15-25{ }^{\circ} \mathrm{C}$ selama 30 menit. Kemudian incubation solution dibuang dengan cara aspirasi atau inverting dan masing-masing well selanjutnya dicuci dengan washing solution (solution 4) $250 \mu \mathrm{l}$ sebanyak tiga kali masingmasing selama tiga menit dan selanjutnya washing solution dibuang dengan cara aspirasi atau inverting.

\section{Pengukuran ELISA dan Fotometrik}

Microplates yang telah di-coating dan diblocking, diisi masing-masing sampel (masingmasing sampel untuk apoptosis dan nekrosis sebanyak $100 \mu \mathrm{l}$ ), kemudian MP ditutup dengan adhesive cover foil dan diinkubasi pada suhu 15$25{ }^{\circ} \mathrm{C}$ selama 90 menit, dan selanjutnya solution dibuang dengan cara aspirasi atau inverting. Masing-masing well selanjutnya dicuci dengan washing solution (solution 4) $250 \mu$ sebanyak tiga kali masing-masing selama tiga menit, sementara cucian yang terakhir dibiarkan, dan microplate tanpa tutup diletakkan diatas beaker glass 500 $\mathrm{ml}$ yang sudah diisi $300 \mathrm{ml}$ air pada microwave oven, di-irradiate selama 5 menit pada $500 \mathrm{~W}$, kemudian didinginkan pada suhu $-20{ }^{\circ} \mathrm{C}$ selama 10 menit. Selanjutnya fluid dibuang dengan cara aspirasi atau inverting. Masing-masing well kemudian ditambah $100 \mu \mathrm{l}$ anti-BrdU-POD conjugate solution (solution 6), dan ditutup dengan adhesive cover foil dan diinkubasi pada suhu $2-8{ }^{\circ} \mathrm{C}$ overnight (ON), kemudian masingmasing well dicuci dengan washing solution (solution 4) $250 \mu$ l sebanyak tiga kali masingmasing selama tiga menit. Substrate solution dipipet sebanyak $100 \mu \mathrm{l}$ dan dimasukkan pada masing-masing well, selanjutnya microplate dishaker dalam keadaan gelap sampai terjadi perubahan warna. Stop solution (solution 8) sebanyak $25 \mu \mathrm{l}$ ditambahkan pada masing-masing well selama lima menit. Pembacaan nilai absorbansi dilakukan pada $\lambda 450 \mathrm{~nm}$ setelah penambahan stop solution.

\author{
Identifikasi protein PPAR $\gamma$ dengan \\ imunositokimia
}

Hasil kultur sel endotel masing-masing perlakuan difiksasi dengan formalin $10 \%$ dalam PBS $\mathrm{pH} 7,4$ selama 20 menit. Sel dicuci dengan PBS $\mathrm{pH} 7,4$ sebanyak tiga kali selama masing-masing lima menit. Sel ditetesi dengan $0,02 \%$ sodium azide. Jaringan dapat disimpan dalam lemari pendingin untuk beberapa hari. Jaringan dicuci dengan PBS pH 7,4 tiga kali selama lima menit. Jaringan ditetesi dengan larutan $\mathrm{H}_{2} \mathrm{O}_{2}$ dalam PBS selama 10 menit. Sel ditetesi dengan blocking serum 5\% FBS yang mengandung Triton-X 0,25\% selama satu jam. Sel dicuci dengan PBS. Inkubasi antibodi primer PPAR $\gamma$ dalam serum 1:200 selama 24 jam. Jaringan disimpan pada suhu 4 ${ }^{\circ} \mathrm{C}$. Jaringan dikeluarkan pada suhu ruang selama 15 menit. Jaringan dicuci dengan PBS dua kali masing-masing selama lima menit. Sel diinkubasi dengan antibodi sekunder biotin-goat-anti rabbit 1:400 selama satu jam pada suhu ruang. Jaringan dicuci dengan PBS dua kali selama masingmasing lima menit. Sel ditetesi dengan SA-HRP (Strep Avidin Horseradish Peroxidase) 1:500 selama satu jam kemudian dicuci dengan PBS sebanyak dua kali masing-masing selama lima menit. Sel ditetesi dengan DAB (Diamino Benzidine) dalam buffer DAB. Sel ditetesi dengan courstexin selama 10 menit. Jaringan dicuci dengan akuades selama 10 menit. Jaringan ditetesi dengan Mayer Hematoxilen selama 10 menit. Jaringan dicuci dengan PBS selama tiga kali masing-masing 10 menit. Jaringan dicuci dengan akuades selama 10 menit. Jaringan dibiarkan pada suhu kamar. Jaringan diletakkan pada object glass dan ditetesi dengan entelan. Setelah itu dibiarkan semalam. Kemudian diamati.

Pengukuran kadar $\mathrm{H}_{2} \mathrm{O} 2$ dengan Colorimetric Hidrogen Peroxide Kit (Assay Design)

Pengukuran kadar $\mathrm{H}_{2} \mathrm{O}_{2}$ dari medium kultur menggunakan Colorimetric Hidrogen Peroxide Kit (Assay Design). Larutan standar dibuat dengan melarutkan $34 \mu \mathrm{l}$ stok Hydrogen Peroxide Standar dengan $966 \mu \mathrm{l}$ diluent dan disebut sebagai larutan standar I. Larutan standar II dibuat dengan melarutkan $500 \mu$ larutan standar I dengan $500 \mu \mathrm{l}$ diluent. Dibuat hingga larutan standar 6 dengan cara yang sama. Kemudian dimasukkan $50 \mu \mathrm{l}$ diluent pada well pertama sebagai larutan blanko, $50 \mu$ l larutan standar I-IV ke dalam well selanjutnya. Masing-masing larutan sampel di-ambil $50 \mu$ dimasukkan ke dalam well. Selanjut-nya semua well 
ditambahkan $100 \mu \mathrm{l}$ Color Reagent dan dihomogenasi menggunakan pipet selama satu detik. Inkubasi dilakukan pada suhu ruang selama 30 menit. Selanjutnya dibaca dengan Elisa Reader pada panjang gelombang $450 \mathrm{~nm}$.

\section{Pengukuran kadar SOD (Superoksida Dismutase) menggunakan Superoxide Activity Assay Kit (Bio Vision)}

Pengukuran kadar SOD dari medium kultur menggunakan Superoxide Activity Assay Kit. Sampel sebanyak $20 \mu \mathrm{l}$ dimasukkan dalam well, dan larutan blanko $\left(\mathrm{H}_{2} \mathrm{O}\right)$ dua well masing-masing sebanyak $20 \mu \mathrm{l}$. Kemudian pada masing-masing well ditambahkan $200 \mu$ l WST (Working Solution). Blank 2 ditambahkan $20 \mu$ dilution buffer. Lalu pada masing-masing well kecuali blank 2 ditambahkan $20 \mu \mathrm{l}$ enzyme working solution. Selanjutnya diinkubasi selama 20 menit pada suhu $37{ }^{\circ} \mathrm{C}$. Kemudian dibaca pada panjang gelombang $450 \mathrm{~nm}$. Dilakukan tiga kali ulangan.

\section{Analisis Data}

Jumlah sel yang mengekspresikan VCAM-1 dan PPAR- $\gamma$ tiap 100 sel, sedangkan pengukuran apoptosis dan nekrosis pada setiap perlakuan kultur sel endotel dilakukan dengan metode ELISA. Setiap unit percobaan diulang tiga kali. Data yang diperoleh dianalisis statistik menggunakan metode analisis satu jalur (ANOVA) dan dilanjutkan dengan uji tukey.

\section{HASIL DAN PEMBAHASAN}

Kultur Human Umbilikus Vein Endothelial Cells (HUVECs)

Kultur sel endotel manusia (HUVECs) diperoleh dari vena umbilikus manusia. Umbilikus yang digunakan harus memenuhi kriteria inklusi, yaitu didapatkan dari hasil persalinan Sectio Caesaria (SC) yang meliputi kehamilan fisiologis (normal), kehamilan dengan pinggul sempit dan kehamilan dengan letak melintang. Sedangkan umbilikus hasil persalinan SC yang tidak boleh digunakan adalah kehamilan disertai infeksi, hipertensi atau kondisi ketuban pecah dini.

Umbilikus yang didapat dari hasil persalinan disimpan dalam media transport (cord solution) dengan komposisi NaBic, M199 dan gentamycin. Penyimpanan dalam medium ini bertujuan untuk mempertahankan kondisi fisiologi umbilikus sebelum dilakukan kultur. Umbilikus harus segera ditumbuhkan paling lama 12 jam setelah proses persalinan agar kondisi sel yang didapatkan setelah ditumbuhkan dapat optimal. Sel endotel digunakan dalam penelitian ini karena menurut Boulomie et al., HUVEC mengekspresikan reseptor fungsional terhadap leptin yang merupakan produk dari ob gene [13].

Sel endotel ditumbuhkan dalam medium komplit yang terdiri dari M199 yang mengandung FBS $10 \%$. Hasil yang diperoleh dari kultur endotel yang confluent pada hari ke-4 (Gambar 1). Sel confluent dicirikan dengan populasi sel yang memenuhi tempat attachment dan saling bersentuhan antar sel menandakan adanya hubungan komunikasi agar sel tumbuh. Dalam keadaan ini, sel siap diperlakukan untuk keperluan penelitian

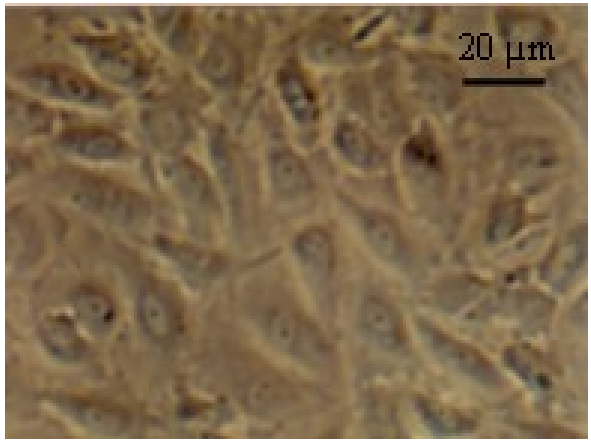

Gambar 1. Kultur endotel normal confluent hari ke-4 pada perbesaran 400 kali
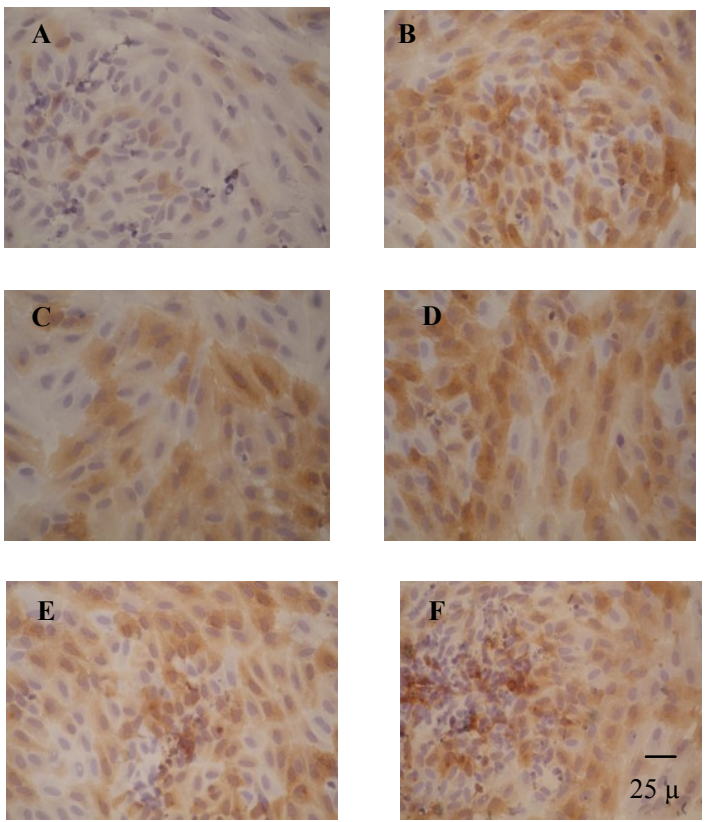

Gambar 2. Hasil imunositokimia ekspresi VCAM-1 pada kultur sel endotel berbagai perlakuan (perbesaran 400 kali)

Keterangan:
A. Leptin $0 \mathrm{ng} \mathrm{ml}^{-1}+$ puerarin $0 \mu \mathrm{M}$
B. Leptin $25 \mathrm{ng} \mathrm{ml}^{-1}$
C. Leptin $25 \mathrm{ng} \mathrm{ml}^{-1}+$ puerarin $5 \mu \mathrm{M}$
D. Leptin $25 \mathrm{ng} \mathrm{ml}^{-1}+$ puerarin $25 \mu \mathrm{M}$
E. Leptin $25 \mathrm{ng} \mathrm{ml}^{-1}+$ puerarin $200 \mu \mathrm{M}$
F. Leptin $25 \mathrm{ng} \mathrm{ml}^{-1}+$ puerarin $525 \mu \mathrm{M}$ 


\section{Analisis ekspresi VCAM-1}

Pada kultur sel endotel, ekspresi VCAM-1 dapat dilihat dengan menggunakan metode imunositokimia dengan menggunakan kromo-gen DAB yang akan berikatan dengan SA-HRPantibodi sekunder (anti mouse)-antibodi primer (mouse monoclonal VCAM-1) terhadap VCAM-1 pada sel endotel. Kompleks avidin-biotin terbentuk antara SA-HRP dengan antibodi sekunder. Substrat DAB membentuk kompleks dengan peroksidase pada SA-HRP membentuk kromogen yang tervisualisasi sebagai warna coklat. Ekspresi VCAM-1 pada kultur sel endotel dengan berbagai perlakuan dapat dilihat pada gambar 2 .

Rata-rata jumlah sel yang mengekspresikan VCAM-1 dituliskan dalam bentuk persentase (Tabel 1). Data pada Tabel 1, menunjukkan bahwa pada kultur sel endotel dengan leptin $0 \mathrm{ng}$ $\mathrm{ml}^{-1}$ dan puerarin $0 \mu \mathrm{M}$ rata-rata jumlah sel sebesar $(0,54 \pm 0,15) \%$, sedangkan pada kultur sel endotel yang diinduksi leptin $25 \mathrm{ngml}^{-1}$ ratarata jumlah sel sebesar $(2,86 \pm 0,15) \%$. Hasil uji statistika menunjukkan bahwa induksi leptin pada kultur sel endotel berpengaruh signifikan $(p<0.05)$ terhadap jumlah sel yang mengekspresikan VCAM-1 dibandingkan dengan leptin $0 \mathrm{ng} \mathrm{ml}^{-1}$ dan puerarin $0 \mu \mathrm{M}$. Keadaan ini menunjukkan bahwa sel endotel yang diinduksi dengan leptin dapat meningkatkan ekspresi VCAM-1. Menurut Bouloumie et al., kultur sel endotel yang distimulasi leptin dapat meningkatkan produksi ROS (Reactive Oxygen Species) [13]. Selanjutnya ROS dapat menyebabkan disfungsi sel endotel dengan cara menstimulasi aktivitas selular seperti sitokin dan mengaktifkan faktor transkripsi NF-KB [14].

Tabel 1. Persentase jumlah sel yang mengekspresikan VCAM-1 pada kultur sel endotel yang diinduksi leptin dan puerarin.

\begin{tabular}{ccc}
\hline \multirow{2}{*}{$\begin{array}{c}\text { Dosis } \\
\text { Puerarin } \\
(\mu \mathrm{M})\end{array}$} & $\begin{array}{c}\text { Jumlah sel yang mengekspresikan } \\
\text { VCAM-1 }(\%)\end{array}$ \\
\cline { 2 - 3 } & ${\text { Leptin } 0 \mathrm{ngml}^{-1}}^{\text {Leptin } 25 \mathrm{ngml}^{-1}}$ \\
\hline 0 & $0,54 \pm 0,15^{\mathrm{a}}$ & $2,86 \pm 0,15^{\mathrm{d}}$ \\
5 & $0,92 \pm 0,40^{\mathrm{ab}}$ & $1,92 \pm 0,05^{\mathrm{bcd}}$ \\
25 & $1,23 \pm 0,38^{\mathrm{abc}}$ & $2,12 \pm 0,26^{\mathrm{cd}}$ \\
200 & $0,77 \pm 0,36^{\mathrm{a}}$ & $2,08 \pm 0,25^{\mathrm{cd}}$ \\
525 & $0,85 \pm 0,34^{\mathrm{a}}$ & $2,22 \pm 0,69^{\mathrm{cd}}$ \\
\hline
\end{tabular}

Keterangan: notasi yang berbeda menunjukkan beda nyata $(\alpha 0,05)$

Perlakuan leptin $0 \mathrm{ng} \mathrm{ml}^{-1}$ dengan puerarin 5, 25, 200 dan $525 \mu \mathrm{M}$ tidak berpengaruh signifikan terhadap leptin $0 \mathrm{ng} \mathrm{ml}^{-1}$ dan puerarin $0 \mu \mathrm{M}$.
Pada Gambar 3, dapat dilihat dosis puerarin 5 dan $25 \mu \mathrm{M}$ cenderung mengalami kenaikan jumlah sel yang mengekspresikan VCAM-1 ( 0,92 $\pm 0,40) \%$ dan $(0,85 \pm 0,34) \%$. Hal ini diduga disebabkan oleh perubahan ekspresi eNOS dapat mengakibatkan gangguan sintesis NO sehingga ekspresi NF- $\mathrm{B}$ B meningkat dan menyebabkan ekspresi VCAM-1. Menurut Lawrence, radikal bebas NO dihasilkan oleh tiga isoform nitric oxide synthase (NOS) yaitu neuronal NOS (nNOS), inducible NOS (iNOS) dan endothelial NOS (eNOS). eNOS merupakan komponen yang paling berperan dalam menjaga homeostasis vaskuler dan terlibat langsung pada patobiologi disfungsi endotel. eNOS akan mengkatalisis produksi NO dari endotel bila dalam keadaan di-coupled oleh tetrahhydrobiopteerin $\left(\mathrm{BH}_{4}\right)$ dan L-arginin. Dalam keadaan uncoupled state, eNOS kekurangan Larginin atau $\mathrm{BH}_{4}$ sehingga terjadi produksi $\mathrm{O}_{2}{ }^{*}$ dan $\mathrm{H}_{2} \mathrm{O}_{2}$ yang terjadi pada disfungsi endotel sehingga menurun-kan bioavaibilitas NO [15]. Sedangkan untuk dosis 200 dan $525 \mu \mathrm{M}$, jumlah sel yang mengekspresi-kan VCAM-1 cenderung mengalami penurunan, dengan jumlah penurunan yang paling besar ada pada dosis puerarin $200 \mu \mathrm{M}$.

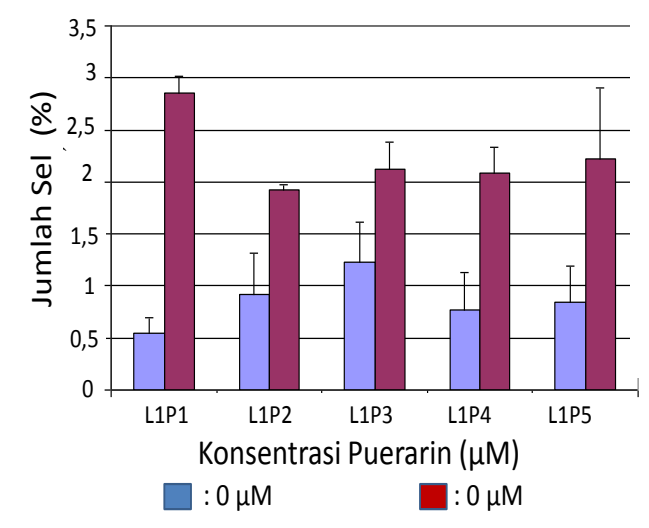

Gambar 3. Hubungan konsentrasi puerarin dengan jumlah sel yang mengekspresikan VCAM-1

Perlakuan leptin $25 \mathrm{ng} \mathrm{ml}^{-1}$ dengan penambahan puerarin 5, 25, 200 dan $525 \mu \mathrm{M}$ tidak menunjukkan hasil yang signifikan, tetapi ada kecenderungan penurunan jumlah sel yang mengekspresikan VCAM-1 pada puerarin $5 \mu \mathrm{M}$. Hal ini menandakan bahwa puerarin dapat menghambat ekspresi VCAM-1 pada sel endotel yang disebabkan oleh efek antioksidan puerarin sehingga mencegah inflamasi. Tetapi pada penelitian ini, dosis puerarin tidak menurunkan ekspresi VCAM-1 mendekati kondisi leptin $0 \mathrm{ng} \mathrm{ml} \mathrm{ml}^{-1}$ (Gambar 3). Hal ini disebabkan 
pemberian puerarin terlambat dalam mencegah aktivasi gen yang mengkode VCAM-1. Menurut Bouloumie et al., dalam jangka waktu 30 menit (10 $\mathrm{ng} \mathrm{ml}^{-1}$ ) leptin sudah mampu meningkatkan level NF- $\kappa \mathrm{B}$, namun dalam penelitian ini, puerarin diberikan setelah enam jam inkubasi dengan leptin [15]. Sedangkan menurut Ding et al., puerarin mampu menurunkan level NF- $\kappa B$ setelah 24 jam [16].

Penelitian ini mengkaji tentang pengaruh puerarin terhadap sel endotel yang diinduksi leptin $25 \mathrm{ng} \mathrm{ml}^{-1}$ dengan melihat adanya penurunan ekspresi pada VCAM-1 yang merupakan biomarker terjadinya disfungsi endotel. Leptin merupakan sitokin yang dihasilkan oleh sel adiposit, dalam jumlah tinggi, leptin dapat menyebabkan terbentuknya ROS dalam sel endotel. ROS melalui aktivasi ERK $1 / 2$ akan meng-induksi CRP. Selanjutnya CRP menginduksi eks-presi VCAM-1 melalui protein kinase $C(P K C)$, p38 mitogen-activated protein kinase (MAPK), tyrosin kinase dan NF-KB [6].

Pada Gambar 4, dalam bentuk tidak aktif NF$\kappa B$ akan berikatan dengan I $\kappa-B$ dimana NF- $\kappa B$ mempunyai dua sub-unit yaitu P65 dan P50.
Molekul tunggal I $\mathrm{\kappa}-\mathrm{B}$ menempel pada domain $\mathrm{N}$ terminal dari setiap unit heterodimer p50/p65, karenanya menutupi nuclear localization signal. Protein kinase komplek yang disebut IK-B kinase merupakan titik berkumpulnya semua sinyal ekstraselular yang mengaktivasi NF- $\kappa$ B. Dalam hitungan menit, stimulasi $\mathrm{I} \kappa-\mathrm{B}$ kinase menjadi teraktifasi dan memfosforilasi dua $\mathrm{N}$-terminal serine residues pada IK-B. E3 ubiquitin ligase kemudian berikatan terhadap phosphoserines dan mem-polyubiquitin IK-B kemudian memicu dengan segera degradasi oleh proteosome. Akibat IK-B terdegradasi, nuclear-localization signal pada NF- $\kappa \mathrm{B}$ menjadi terekspos sehingga dapat bertranslokasi kedalam inti sel dan mengaktifasi transkripsi dari berbagai macam gen target. Pensinyalan NF- $\mathrm{KB}$ dihentikan oleh negatif feedback loop, dimana setiap satu gen yang ditranskripsinya diinduksi langsung oleh NF- $\kappa B$ juga mengkodekan I $\mathrm{K}-\mathrm{B}$. Akhirnya level protein I $\kappa-B$ yang tinggi menonaktifkan NF- $\kappa B$ aktif di dalam sel dan mengembalikannya ke sitosol. Dengan pemberian puerarin dapat mencegah terjadinya disfungsi endotel.

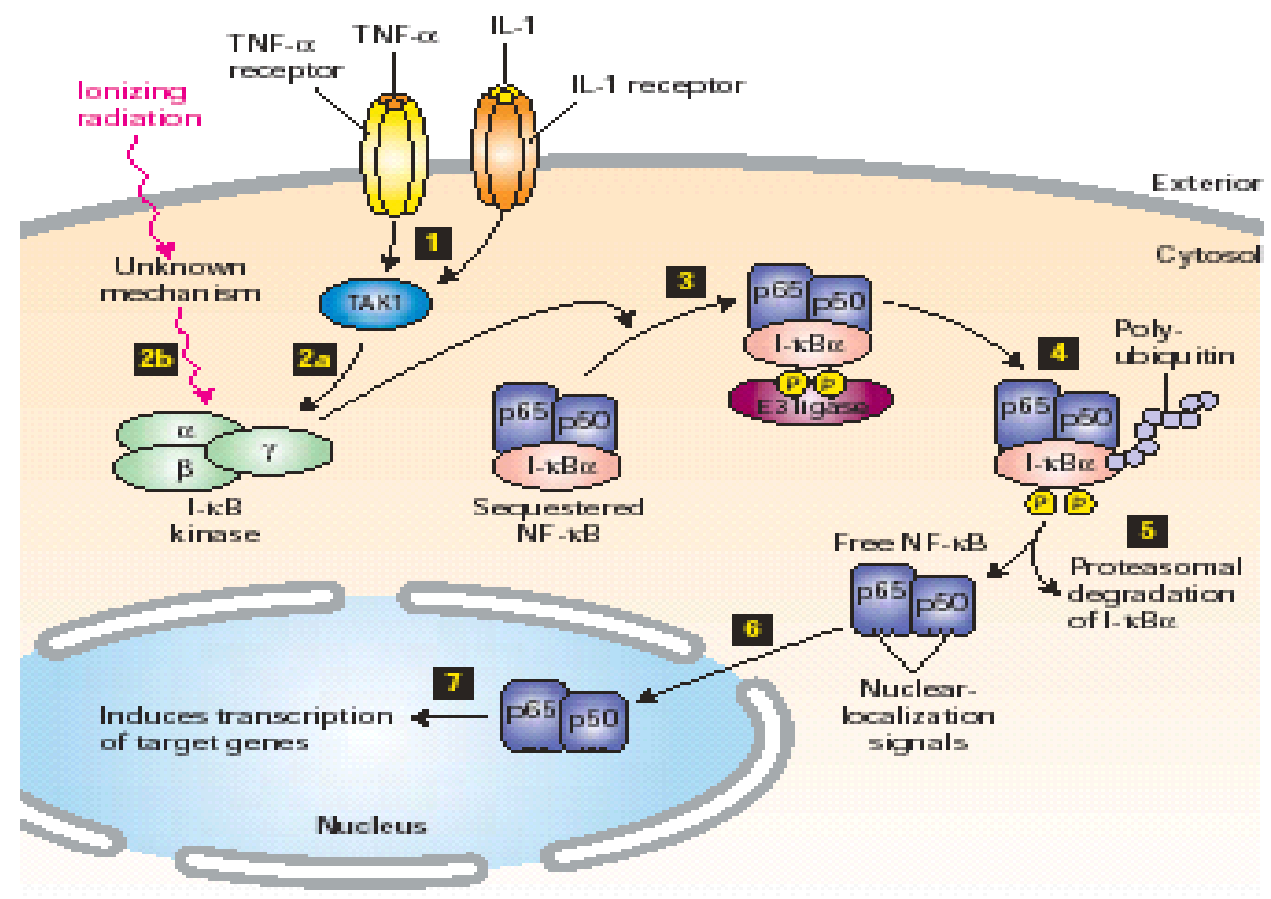

Gambar 4. Jalur sinyal NF-кB [17]

Keterangan:

(1) stimulasi oleh TNF- $\alpha$ atau IL-1 menginduksi aktivasi TAK-1 kinase. (2a) aktivasi trimerik IK-B kinase. (2b) radiasi pengion dan stress lainnya dapat secara langsung mengaktivasi IK-B kinase dengan mekanisme yang belum diketahui. (3) phosporilasi

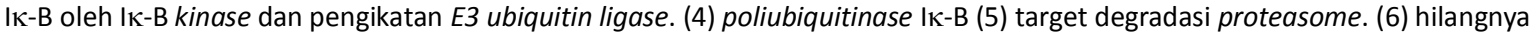
ІК-B membuka nuclear localization dari ke dua sub unit NF-KB. (7) NF-KB mengaktivasi transkripsi dari beberapa target gen termasuk sub unit $\alpha$ dari lK-B yang bertindak untuk menghentikan sinyal. 
Puerarin akan menginduksi endothelial nitric oxide synthase (eNOS) sehingga menghasilkan NO yang meru-pakan vasodilatator dan dapat meningkatkan ekspresi IK-B dan menurunkan ekspresi VCAM-1 [3]. Namun dosis puerarin yang digunakan pada penelitian ini kurang bervariasi sehingga sulit untuk menentukan dosis optimumnya dalam mengurangi resiko inflamasi dan disfungsi endotel, selain itu ada perbedaan waktu pemberian puerarin dengan leptin sehingga puerarin baru bekerja setelah leptin menginduksi ekspresi VCAM-1 pada sel endotel.

Pendugaan terhadap puerarin sebagai terapi disfungsi endotel yaitu puerarin dapat secara langsung mempengaruhi ekspresi VCAM-1 dimana puerarin merupakan scavenger dari VCAM-1. Berdasarkan hasil penelitian Prasain diketahui bahwa puerarin dapat diabsorbsi secara cepat dan sempurna dengan hipotesis bahwa puerarin diduga ditransportasikan menyeberangi dinding intestinal dan diabsorbsi secara sempurna tanpa metabolisme [18]. Selain itu berdasarkan penelitian yang dilakukan oleh Sun et al., puerarin diketahui sebagai terapi penyakit kardiovaskular tetapi mekanisme puerarin terhadap disfungsi endotel belum diketahui [19].

\section{Analisis Ekspresi PPAR}

Analisis ekspresi PPAR- $\gamma$ pada kultur sel endotel (HUVECS) dapat dilakukan vivo dengan teknik imunositokimia yang menggunakan antibodi primer PPAR- $\gamma$ dalam serum 1:200 dan antibodi sekunder biotin-goat-anti rabbit 1: 400. Ekspresi PPAR- $\gamma$ dideteksi dari warna coklat pada sitoplasma sel endotel. Ekspresi PPAR- $\gamma$ pada kultur sel endotel dengan berbagai perlakuan dapat dilihat pada Gambar 5.

Berdasarkan hasil perhitungan menunjukkan bahwa pada kultur sel endotel yang diinduksi leptin $25 \mathrm{ng} \mathrm{ml}^{-1}$, terjadi peningkatan jumlah sel yang mengekspresikan PPAR- $\gamma$ sebanyak $(3,37 \pm$ $0,35) \%$. Sedangkan pada leptin $0 \mathrm{ng} \mathrm{ml}^{-1}$, jumlah sel yang mengekspresikan PPAR- $\gamma$ hanya sebanyak (0,9 $\pm 0,22) \%$. Hasil uji statistik menyatakan bahwa induksi leptin $25 \mathrm{ng} \mathrm{ml}^{-1}$ berpengaruh signifikan $(p<0,05)$ terhadap jumlah sel yang mengekspresikan PPAR- $\gamma$

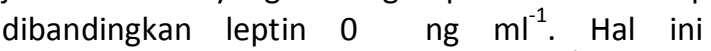
menunjukkan bahwa leptin $25 \mathrm{ng} \mathrm{ml}^{-1}$ mampu meningkatkan jumlah ekspresi PPAR- $\gamma$ (Gambar 6). Pada dasarnya PPAR- $\nu$ juga telah diekspresikan di sel endotel (normal) tetapi dalam jumlah yang sedikit sehingga dengan induksi leptin $25 \mathrm{ng} \mathrm{m}^{-1}$ mampu meningkatkan ekspresi PPAR- $\gamma$ bila dibandingkan dengan perlakuan tanpa leptin (leptin $0 \quad \mathrm{ng} \mathrm{ml}^{-1}$ ). Menurut Dadogo et al., menyatakan bahwa konsentrasi leptin dalam darah mencakup 2-10

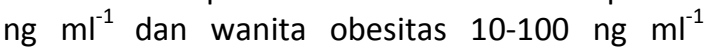
dimana pada batas tersebut leptin dapat meningkatkan jumlah sel [20]. Hal ini sesuai dengan hasil penelitian ini bahwa induksi leptin $25 \mathrm{ng} \mathrm{ml}^{-1}$ dapat meningkatkan jumlah ekspresi PPAR- $\gamma$. Rata-rata jumlah sel yang mengekspresikan PPAR- $\gamma$ pada tiap perlakuan, ditampilkan pada Gambar 6.
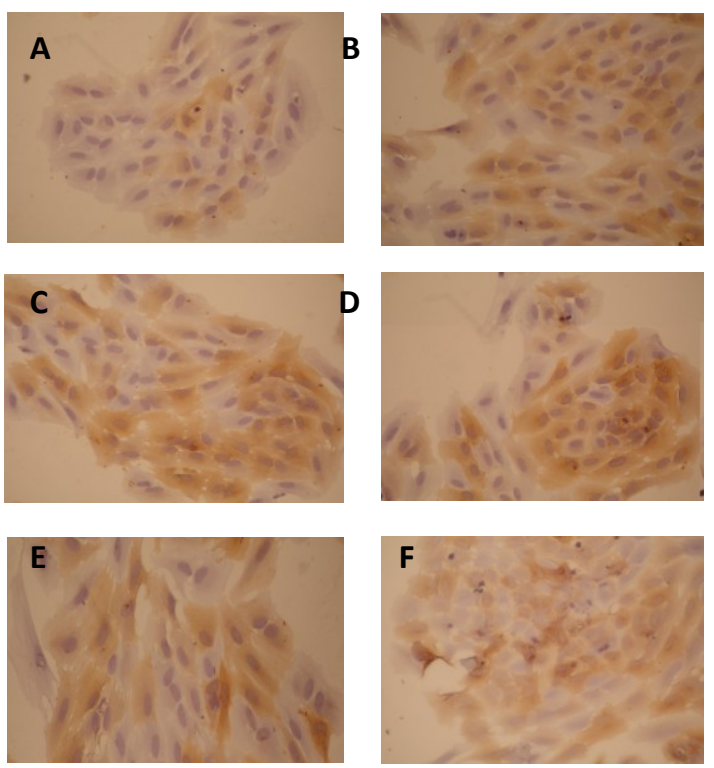

Gambar 5. Hasil imunositokimia PPAR- $\psi$ pada kultur sel endotel (HUVEC'S) dengan berbagai perlakuan

\section{Keterangan:}
A. Leptin $0 \mathrm{ng} \mathrm{ml}^{-1}+$ puerarin $0 \mu \mathrm{M}$
B. Leptin $25 \mathrm{ng} \mathrm{ml}^{-1}$
C. Leptin $25 \mathrm{ng} \mathrm{ml}^{-1}+$ puerarin $5 \mu \mathrm{M}$
D. Leptin $25 \mathrm{ng} \mathrm{ml}^{-1}+$ puerarin $25 \mu \mathrm{M}$
E. Leptin $25 \mathrm{ng} \mathrm{ml}^{-1}+$ puerarin $200 \mu \mathrm{M}$
F. Leptin $25 \mathrm{ng} \mathrm{ml}^{-1}+$ puerarin $525 \mu \mathrm{M}$

Pada perlakuan leptin $0 \mathrm{ng} \mathrm{ml}^{-1}$ dengan penambahan puerarin masing-masing 5, 25, 200 dan $525 \mu \mathrm{M}$ tidak berpengaruh signifikan ( $\mathrm{p}<$ $0,05)$, tetapi ada kecenderungan peningkatan ekspresi PPAR- $\gamma$ dibandingkan leptin $25 \mathrm{ng} \mathrm{ml}{ }^{-1}$, yang ditunjukkan pada Gambar 6. Hal ini diduga disebabkan oleh konsentrasi puerarin yang kurang tinggi dan kurang bervariasi dalam menurunkan ekspresi PPAR- $\gamma$. Kenaikan ekspresi PPAR- $\gamma$ ini dapat berpengaruh pada kenaikan faktor-faktor transduksi yang lain yang dapat memicu terjadinya disfungsi endotel. Menurut Delerive et al., peningkatan PPAR- $\gamma$ dapat menyebabkan aterosklerosis, resistensi insulin, hipertensi dan diabetes tipe 2. Aktivasi PPAR- $\nu$ 
dalam sel dapat meningkatkan faktor-faktor seperti proliferasi sel endotel, AT-II (angotensinII), PAI-1 (plasminogen-1), ET-1 (endothelin-1), VCAM-1 dan E-selectin, sebagai awal terjadinya aterosklerosis. Kemung-kinan kedua disebabkan oleh puerarin sebagai antioksidan, ketika dalam jumlah yang berlebih di dalam sel justru akan menyebabkan prooksidan. Puerarin berpotensi untuk menginduksi diferen siasi preadiposit, mem-promote glukosa uptake dari adiposit yang kemudian menginduksi resistensi insulin oleh glukosa tinggi [21].

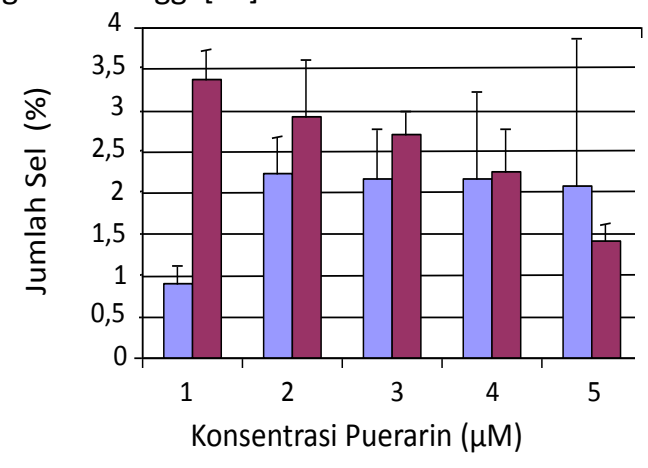

: Leptin $0 \mathrm{ngml}^{-1} \quad$ : Leptin $25 \mathrm{ngml}^{-1}$

Gambar 6. Hubungan konsentrasi puerarin dengan jumlah sel yang mengekspresikan PPAR- $\psi$

Pada kultur sel endotel yang diinduksi leptin $25 \mathrm{ng} \mathrm{ml}^{-1}$ dengan penambahan puerarin masingmasing 5, 25, 200 dan $525 \mu \mathrm{M}$ jumlah sel yang mengekspresikan PPAR $-\gamma$ berurutan masingmasing sebanyak $(2,93 \pm 0,68) \%,(2,72 \pm 0,27) \%$, $(2,26 \pm 0,51) \%, \quad(1,42 \pm 0,20) \%$. Hasil uji statistik menyatakan bahwa antara induksi leptin 25 $\mathrm{ng} \mathrm{ml}^{-1}$ dengan masing-masing puerarin 5, 25, $200 \mu \mathrm{M}$ menunjukkan penurunan terhadap jumlah sel yang mengekspresikan PPAR- $\gamma$, tetapi tidak signifikan. Namun pada konsentrasi puerarin $525 \mu \mathrm{M}$ ada kecenderungan penurunan ekspresi PPAR- $\gamma$. Konsentrasi puerarin $525 \mu \mathrm{M}$ adalah konsentrasi yang mampu menurunkan ekspresi PPAR- $\gamma$ hampir mendekati kondisi sel endotel yang diinduksi leptin $0 \mathrm{ng} \mathrm{ml}^{-1}$ (sel endotel normal) (Gambar 6). Namun pada penelitian ini tidak dilakukan penggunaan dosis atau konsentrasi puerarin yang lebih tinggi dan bervariasi lagi sehingga dapat diketahui konsentrasi puerarin yang optimal dalam menurunkan jumlah ekspresi PPAR- $\gamma$ serta aman untuk digunakan. Menurut Hill et al., puerarin dilaporkan mempunyai efek mencegah disfungsi endotel yang diinduksi oleh banyak factor [8]. Penelitian menggunakan isoflavon ini juga dilaporkan telah mempunyai efek antidiabetik melalui jalur PPAR pada tikus obese, diabetes tipe 2 dan penyakit kardio-vaskuler [22]. Injeksi puerarin dapat menurunkan kerusakan oksidatif pada sel dan menghambat apoptosis [23].

Senyawa aktif puerarin menyebabkan penurunan ekspresi PPAR- $\gamma$ memiliki kemungkinan jalur penghambatan, yaitu melalui penghambatan ROS. Puerarin juga melakukan penghambatan jalur signal transduksi (down regulation) jalur MAPK khususnya Erk 1/2 [8]. Selain itu diduga puerarin bertindak sebagai Scavanger terhadap penurunan ekspresi PPAR- $\gamma$. Mekanisme keja senyawa aktif puerarin kemungkinan langsung memblokir aktivasi PPAR $-\gamma$ pada binding site tempat ligan berikatan pada PPAR- $\nu$ dan hal ini masih memerlukan penelitian secara in vitro lebih lanjut. Pada penelitian ini induksi puerarin digunakan sebagai agen terapi untuk disfungsi endotel. Apabila ekspresi dan aktivasi dari PPAR- $\gamma$ terhambat atau menurun oleh adanya induksi puerarin, proses akhir dalam hal ini disfungsi endotel juga akan terhambat dan secara tidak langsung dapat menurunkan tahapan disfungsi endotel.

Pada penelitian ini, kultur sel endotel yang diinduksi leptin $25 \mathrm{ng} \mathrm{ml}^{-1}$ mampu meningkatkan jumlah sel yang mengekspresikan PPAR- $\psi$. Hal ini disebabkan karena peran leptin sebagai faktor penginduksi (inducer) dan kemampuan leptin dalam meningkatkan ekspresi PPAR- $\gamma$. Leptin yang tinggi didalam sel endotel meningkatkan LDL teroksidasi yang menyebabkan kerusakan endotel. Pada kondisi tersebut terjadi peroksidase lipid, inflamasi dan peningkatan ROS (Reactive Oxygen Species) sebagai second messenger dan kemung-kinan mengaktifkan proses atherogenik, seperti halnya sitokin proinflamatory [13]. ROS sebagai second messenger, bertindak dalam transduksi stimuli ekstraseluler dan intraseluler, sebagai contoh jalur Erk 1/2 (extracellular-regulated kinases). Peningkatan Erk $1 / 2$ ini berasosiasi dengan peningkatan proliferasi sel dan diferen-siasi [24]. Leptin dapat meningkatkan PPAR- $\gamma$ melalui jalur MAP kinases (Mitogen Activated Protein Kinases) khususnya Erk $1 / 2$. Jalur MAP Kinase meregulasi dari berbagai proses penting seperti proliferasi, diferensiasi hingga apoptosis. Selanjutnya menginduksi dan mengaktivasi pem-bentukan protein c-jun dan c-fos yang merupakan komponen (protein) penyusun utama faktor transkripsi AP-1. Faktor transkripsi AP-1 adalah faktor transkripsi yang dapat diaktifkan dan diregulasi pada level transkripsional maupun protein [25]. AP-1 berikatan dengan C/EBP $\alpha$ (CCAAT/Enhancer Binding Protein), yang dapat 
mengaktivasi faktor transkripsi seperti PPARy di nukleus [26]. Jalur MAPK ini merupakan jalur responsibel untuk leptin dalam menginduksi aktivasi c-fos. Pada akhirnya mengaktivasi faktor transkripsi [27]. Model leptin signaling dapat dilihat pada Gambar 7.

\section{Aktivitas Superoksida Dismutase (SOD)}

Pengukuran aktivitas enzim SOD ditandai dengan terjadinya peningkatan kadar SOD pada medium kultur sel endotel (HUVECs). Deteksi kadar SOD menggunakan ELISA Kit karena dianggap lebih sensitif (pengukuran hingga kadar nano gram $\left.\left[10^{-9}\right]\right)$ sehingga hasil yang didapat dapat lebih akurat. Obyek yang diukur pada penelitian ini adalah extracellular SOD (EC-SOD) yang terkandung dalam medium kultur. Menurut Grayck et al., EC-SOD mayoritas diekspresikan di beberapa jaringan termasuk jaringan vaskuler, paru-paru, dan uterus. EC-SOD tersusun dari 70\% dari total aktivitas SOD pada manusia [28].

Hasil perhitungan kadar SOD dengan tiga kali ulangan didapatkan rata-rata kadar SOD seperti digambarkan pada Gambar 8. Data dianalisis menggunakan uji statistik. Berdasarkan hasil pengukuran diketahui bahwa aktivitas SOD terukur pada semua perlakuan. Berdasarkan konsentrasi puerarin yang diperlakukan (pada Gambar 8), pada puerarin $0 \mu \mathrm{M}$, paparan leptin 0 $\mathrm{ng} \mathrm{ml}^{-1}$ menunjukkan kadar SOD yang sedikit lebih tinggi yaitu $0,027 \%$ jika dibandingkan dengan paparan leptin $25 \mathrm{ng} \mathrm{ml}^{-1}$ yaitu $0,025 \%$. Hal ini juga ditunjukkan pada perlakuan puerarin $5 \mu \mathrm{M}$ dimana paparan leptin $0 \mathrm{ng} \mathrm{ml}^{-1}$ kadar SOD yang terukur lebih tinggi yaitu sebesar 0,031\% jika dibandingkan dengan leptin $25 \mathrm{ng} \mathrm{\textrm {ml } ^ { - 1 }}$ sebesar 0,026. Demikian juga pada perlakuan leptin $25 \mu \mathrm{M}$, kadar SOD pada paparan leptin 0 ng $\mathrm{ml}^{-1}$ lebih tinggi yaitu $0,030 \%$, sedangkan paparan leptin $25 \mathrm{ng} \mathrm{ml}^{-1}$ kadar SOD sebesar $0,028 \%$. Kadar SOD lebih tinggi pada paparan

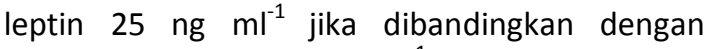

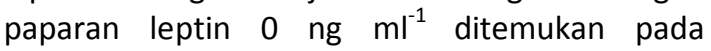
perlakuan puerarin $525 \mu \mathrm{M}$. Dimana paparan leptin $25 \mathrm{ng} \mathrm{ml}^{-1}$ kadar SOD sebesar 0,033\% sedangkan leptin $0 \mathrm{ng} \mathrm{ml}^{-1}$ sebesar 0,031\%. Pada perlakuan puerarin $200 \mu \mathrm{M}$ kadar SOD yang terukur antara paparan leptin $0 \mathrm{ng} \mathrm{ml}^{-1}$ dan leptin $25 \mathrm{ng} \mathrm{ml}^{-1}$ hampir sama, yaitu sebesar 0,0306 dan 0,0309 .

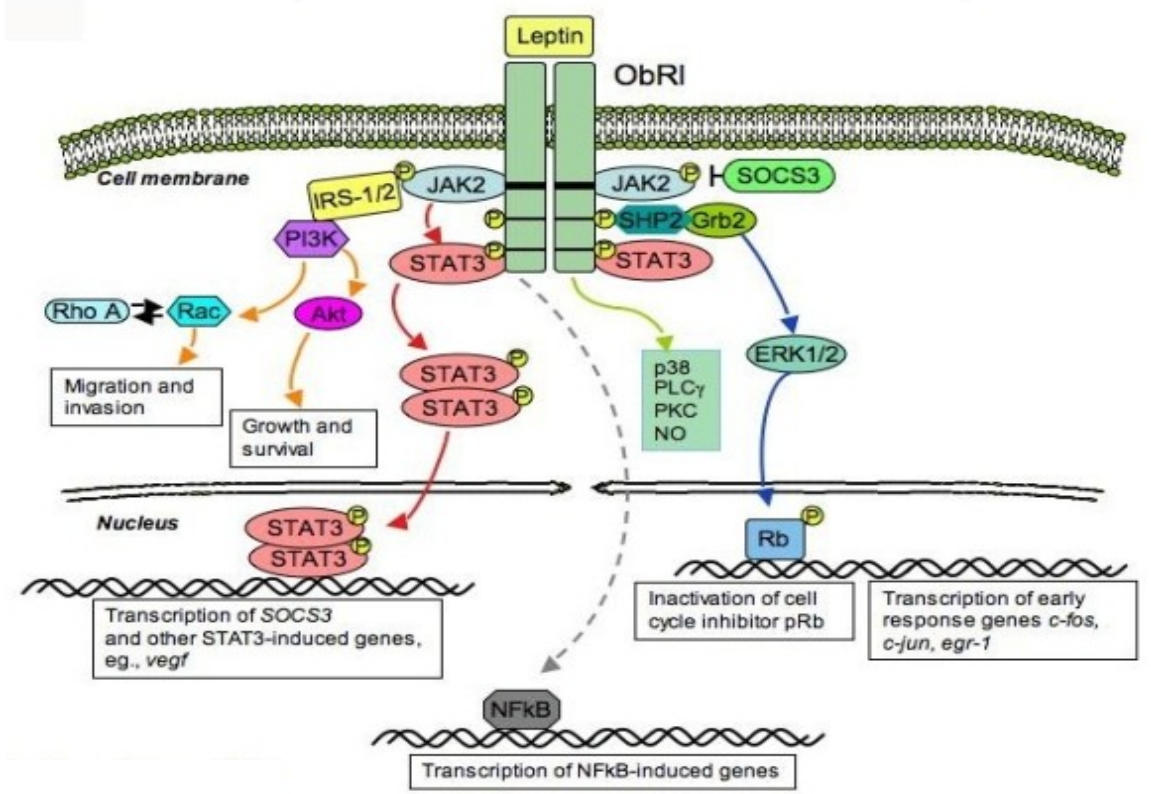

Gambar 7. Leptin signaling mengaktivasi faktor transkripsi melalui jalur Erk 1/2. Aktivasi dari jalur Erk 1/2 akan mengaktivasi c-jun dan c-fos di nukleus, yang selanjutnya dapat mengaktivasi faktor transkripsi yang lain seperti PPARy [29]

Tabel 3. Jumlah fragmen-fragmen DNA yang dilabel $B r d U$ pada sitoplama (apoptosis) dan supernatan (nekrosis).

\begin{tabular}{|c|c|c|c|c|}
\hline \multirow{3}{*}{ Konsentrasi Puerarin $(\mu \mathrm{M})$} & \multicolumn{4}{|c|}{ Jumlah fragmen-fragmen DNA yang dilabel $B r d U$} \\
\hline & \multicolumn{2}{|c|}{ Apoptosis } & \multicolumn{2}{|c|}{ Nekrosis } \\
\hline & Non Leptin & Leptin & Non Leptin & Leptin \\
\hline 0 & $1,6 \pm 0,3$ & $1,2 \pm 0,1$ & $2,2 \pm 0,5$ & $2,1 \pm 0,2$ \\
\hline 5 & $1,2 \pm 0,1$ & $1,1 \pm 0,1$ & $1,9 \pm 0,1$ & $1,7 \pm 0,3$ \\
\hline 25 & $1,3 \pm 0,2$ & $1,1 \pm 0,1$ & $1,9 \pm 0,4$ & $1,5 \pm 0,2$ \\
\hline 200 & $1,2 \pm 0,2$ & $1,4 \pm 0,6$ & $1,6 \pm 0,3$ & $1,9 \pm 0,6$ \\
\hline 525 & $1,3 \pm 0,1$ & $1,8 \pm 0,3$ & $2,3 \pm 0,6$ & $1,9 \pm 0,3$ \\
\hline
\end{tabular}


Hasil uji statistik ( $p$ value $>0,05$ ) menyatakan bahwa variasi konsentrasi puerarin $(0,5,25,200$, $525 \mu \mathrm{M})$ tidak menunjukkan beda nyata terhadap terhadap kontrol (tanpa paparan leptin). Hal ini menunjukkan bahwa konsentrasi leptin $25 \mathrm{ng} \mathrm{ml}^{-}$ ${ }^{1}$ pada kultur sel endotel selama 12 jam belum dapat mempengaruhi aktivitas SOD ekstraselular. Dimana radikal yang dihasilkan dalam mitokondria ini merupakan ROS primer yaitu superoksida $\left(\mathrm{O}_{2}{ }^{*}\right)$ [29]. Sehingga jika jumlah superoksida tinggi, maka superoksida yang ditangkap oleh SOD dan diubah menjadi $\mathrm{H}_{2} \mathrm{O}_{2}$ meningkat sehingga aktivitas SOD juga diharapkan meningkat. Namun aktivitas SOD dalam penelitian ini menunjukkan perbedaan yang tidak nyata.

Hasil penelitian menunjukkan bahwa interaksi antara puerarin dan leptin tunggal belum dapat mempengaruhi aktivitas SOD secara signifikan. Sedangkan menurut pernyataan Yamagishi et al., yang menyatakan bahwa kadar leptin $10 \mathrm{ng} \mathrm{ml}^{-1}$ dalam plasma darah telah dapat menginduksi over produksi ROS. Sedangkan interaksi antara 25 ng $\mathrm{ml}^{-1}$ leptin dan peningkatan konsentrasi puerarin secara bertahap tidak mempengaruhi aktivitas SOD ekstraselular [30]. Dari hasil tersebut diduga pengukuran kadar SOD ekstraselular belum dapat mempresentasikan jumlah super-oksida karena keberadaan SOD intraselular tidak dapat diabaikan jika dilihat dari kadar pengukuran $\mathrm{H}_{2} \mathrm{O}_{2}$. Hal ini dijelaskan oleh Hayden and Tyagi, bahwa adanya Parameter Status Antioksidan Total (SAT) diperlukan untuk dapat menggambarkan status keseimbangan redoks, dan untuk mewakili aktivitas menyeluruh suatu oksidan dan anti-oksidan [31]. Dalam penelitian ini dapat disim-pulkan bahwa puerarin bekerja sinergis dengan SOD dalam menangkap radikal superoksida melalui proses scavenger secara langsung. Hal ini dijelaskan oleh Nijveldt, bahwa flavonoid bertindak sebagai antioksidan untuk mencegah kerusakan yang disebabkan oleh radikal bebas dengan penangkapan oksidan secara langsung (direct scavenging) [32]. Mekanismenya menurut Korkina et al., sebagai berikut, yaitu flavonoid dioksidasi oleh radikal menghasilkan bentuk radikal yang lebih stabil dan kurang reaktif. Dengan kata lain, flavonoid menyetabilkan ROS dengan bereaksi bersama komponen reaktif radikal. Reaktivitas flavonoid bergantung pada gugus hidroksil flavonoid tersebut, yang menye-babkan radikal menjadi inaktif. Pernyataan ini dapat menjelaskan bahwa cara kerja antioksidan flavonoid tidak mengaktivasi antioksidan endo-gen, namun flavonoid (puerarin) bekerja sinergis dengan antioksidan endogen (SOD) dalam menangkap radikal bebas [33]. Selain itu menurut Grayck et al., SOD berperan dalam memodulasi reaksi NO dengan menghambat reaksi antara superoksida dan NO, karena superoksida bereaksi cepat dengan NO menginaktivasi aktivitas vasodilator NO dan membentuk oksidan sekunder kuat yaitu peroksinitrit (OONO') [28].

\section{Kadar Hidrogen Peroksida $\left(\mathrm{H}_{\mathbf{2}} \mathrm{O}_{2}\right)$}

Pengukuran kadar $\mathrm{H}_{2} \mathrm{O}_{2}$ dapat diukur sebagai produk dari aktivitas enzim SOD. $\mathrm{H}_{2} \mathrm{O}_{2}$ dibentuk dari dismutasi superoksida secara spontan pada $\mathrm{pH}$ rendah yang dikatalisis oleh SOD [34].

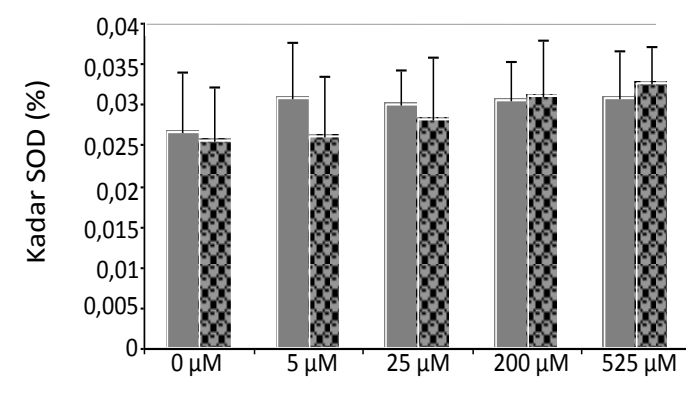

Konsentrasi Puerarin

: Leptin 0 ngml-1 $^{-1}$

83: Leptin 25 ngml- $^{-1}$

Gambar 8. Histogram hubungan konsentrasi puerarin pada kultur sel endotel yang diinduksi $0 \mathrm{ng} \mathrm{ml}^{-1}$ leptin dan $25 \mathrm{ng} \mathrm{ml}^{-1}$ leptin terhadap aktivitas SOD

Hasil pengukuran kadar $\mathrm{H}_{2} \mathrm{O}_{2}$ menggunakan Elisa, diketahui bahwa $\mathrm{H}_{2} \mathrm{O}_{2}$ terukur pada semua perlakuan dengan kadar yang digambarkan pada Gambar 9. Berdasarkan variasi konsentrasi puerarin yang diperlakukan (Gambar 9), pada perlakuan puerarin $0 \mu \mathrm{M}$ dan $5 \mu \mathrm{M}$ menunjukkan kadar $\mathrm{H}_{2} \mathrm{O}_{2}$ yang yang lebih tinggi pada paparan leptin $25 \mathrm{ng} \mathrm{ml}^{-1}$ jika dibandingkan dengan leptin $0 \mathrm{ng} \mathrm{ml}^{-1}$. Yaitu berurutan pada puerarin 0 , puerarin $25 \mu \mathrm{M}$ dan leptin $25 \mu \mathrm{M}$ kadar $\mathrm{H}_{2} \mathrm{O}_{2}$ sebesar $11,42 \mathrm{ng} \mathrm{ml}^{-1}$ sedangkan pada paparan leptin $0 \mathrm{ng} \mathrm{ml}^{-1}$ kadarnya sebesar $10,25 \mathrm{ng} \mathrm{ml}^{-1}$, leptin $25 \mathrm{ng} \mathrm{ml}^{-1}$ kadar $\mathrm{H}_{2} \mathrm{O}_{2}$ sebesar $10,6 \mathrm{ng} \mathrm{ml}^{-1}$ sedangkan leptin $25 \mathrm{ng} \mathrm{ml}^{-1}$ kadar $\mathrm{H}_{2} \mathrm{O}_{2}$ sebesar $10,01 \mathrm{ng} \mathrm{ml}^{-1}$. Pada tiga perlakuan puerarin lainnya yaitu $25 \mu \mathrm{M}, 200 \mu \mathrm{M}$ dan $525 \mu \mathrm{M}$ menunjukkan kadar $\mathrm{H}_{2} \mathrm{O}_{2}$ lebih tinggi pada paparan leptin $0 \mathrm{ng} \mathrm{\textrm {ml } ^ { - 1 }}$ jika diban-dingkan dengan paparan leptin $25 \mathrm{ng} \mathrm{ml}^{-1}$, yang artinya puerarin menurunkan kadar $\mathrm{H}_{2} \mathrm{O}_{2}$. Yaitu masingmasing berurutan berdasarkan konsen-trasi puerarin $25 \mu \mathrm{M}, 200 \mu \mathrm{M}$ dan $525 \mu \mathrm{M}$ dengan konsentrasi paparan leptin 0 dan $25 \mathrm{ng} \mathrm{ml}^{-1}$ 
adalah 9,92 $\mathrm{ng} \mathrm{ml}^{-1}$ lebih tinggi jika dibandingkan dengan 9,12 $\mathrm{ng} \mathrm{ml}^{-1}, 10,32 \mathrm{ng} \mathrm{ml}^{-1}$ lebih tinggi jika dibandingkan 8,08 $\mathrm{ng} \mathrm{m}^{-1}$ dan 10,5 lebih tinggi jika dibandingkan dengan 9,75 $\mathrm{ng} \mathrm{ml}^{-1}$. Hasil uji statistik (berdasarkan perhitungan pada lampiran 6.) menyatakan bahwa penambahan konsentrasi leptin $25 \mathrm{ng} \mathrm{ml}^{-1}$ tidak mempengaruhi secara signifikan kadar $\mathrm{H}_{2} \mathrm{O}_{2}$ yang diproduksi jika dibandingkan dengan sel normal (tanpa paparan leptin). Sedangkan variasi konsentrasi puerarin $(0,5,25,200,525 \mu \mathrm{M})$ menunjukkan beda nyata terhadap kontrol. Berdasarkan uji lanjut BNJ, didapatkan adanya konsentrasi optimum puerarin dalam menurunkan kadar $\mathrm{H}_{2} \mathrm{O}_{2}$ yaitu $200 \mu \mathrm{M}$. Sedang-kan konsentrasi puerarin diatasnya (525 $\mu \mathrm{M})$ menyebabkan kadar $\mathrm{H}_{2} \mathrm{O}_{2}$ meningkat.

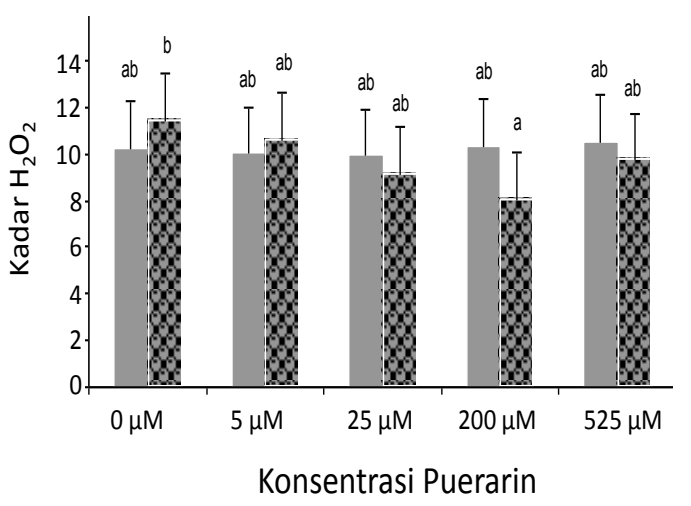

: Leptin $0 \mathrm{ngml}^{-1}$

Gambar 9. Histogram hubungan konsentrasi puerarin pada kultur sel endotel yang diinduksi 0 ngmll $^{-1}$ leptin dan $25 \mathrm{ng} \mathrm{ml}^{-1}$ leptin terhadap kadar $\mathrm{H}_{2} \mathrm{O}_{2}$.

$\mathrm{H}_{2} \mathrm{O}_{2}$ merupakan hasil dari konversi superoksida $\left(\mathrm{O}_{2}{ }^{*}\right)$ dari reaksi dismutasi yang dikatalis oleh SOD. $\mathrm{H}_{2} \mathrm{O}_{2}$ selanjutnya ditransformasi menjadi radikal hidroxil $\left(\mathrm{OH}^{*}\right)$ dengan keberadaan ion metal melalui reaksi Fenton atau Haber-Weiss [31]. Kadar $\mathrm{H}_{2} \mathrm{O}_{2}$ dalam penelitian ini dipengaruhi oleh perlakuan kombinasi $25 \mathrm{ng}$ $\mathrm{ml}^{-1}$ leptin dan puerarin, sesuai dengan pernyataan Zmijewski et al., yang menyatakan bahwa jumlah $\mathrm{H}_{2} \mathrm{O}_{2}$ dalam sel dipengaruhi oleh produksi superoksida dari mitokondria [35].

Perlakuan kombinasi $25 \mathrm{ng} \mathrm{ml}^{-1}$ leptin dan puerarin menunjukkan konsentrasi optimum puerarin dalam menurunkan kadar $\mathrm{H}_{2} \mathrm{O}_{2}$ yaitu $200 \mu \mathrm{M}$. Sedangkan konsentrasi diatasnya yaitu $525 \mu \mathrm{M}$ kembali meningkatkan kadar $\mathrm{H}_{2} \mathrm{O}_{2}$. Hal ini menunjukkan bahwa kondisi antioksidan yang berlebihan jika dibandingkan dengan kadar ROS akan menyebabkan efek negatif yaitu antioksidan dianggap sebagai oksidan dalam sel yang menyebabkan over produksi $\mathrm{H}_{2} \mathrm{O}_{2}$. Hal ini dijelaskan oleh Gordon, bahwa konsentrasi antioksidan yang ditambahkan dapat berpengaruh pada laju oksidasi. Pada konsentrasi tinggi, akti-vitas antioksidan sering lenyap, bahkan berubah sifatnya menjadi prooksidan. Sifat antioksidan yang berubah menjadi prooksidan dijelaskan pada gambar 10 [36].

$$
\begin{array}{lll}
\mathrm{AH}+\mathrm{O}_{2} & \longrightarrow & \mathrm{A}^{*}+\mathrm{HOO}^{*} \\
\mathrm{AH}+\mathrm{ROOH} & \longrightarrow & \mathrm{RO}^{*}+\mathrm{H}_{2} \mathrm{O}+\mathrm{A}^{*}
\end{array}
$$

Gambar 10. Antioksidan bertindak sebagai prooksidan pada konsentrasi tinggi [36]

Berdasarkan persamaan Gambar 10, dapat dimengerti bahwa keberadaan antioksidan yang tidak dibutuhkan (berlebih) akan terdisosiasi dan bersifat radikal. Radikal yang terbentuk akan menangkap oksigen $\left(\mathrm{O}_{2}\right)$ dan hidroperoksida $(\mathrm{ROOH})$ stabil menghasilkan radikal $\mathrm{HOO}^{*}$ dan radikal lipida $\left(\mathrm{RO}^{*}\right)$. Keberadaan $\mathrm{H}_{2} \mathrm{O}_{2}$ yang menurun pada konsentrasi flavonoid optimum (200 $\mu \mathrm{M})$ dan naik pada konsentrasi di atas optimum (525 $\mu \mathrm{M}$ ) mengindikasikan dosis yang berlebih (di atas optimum) meningkatkan produksi radikal superoksida yang menghasilkan peningkatan produksi $\mathrm{H}_{2} \mathrm{O}_{2}$.

\section{Apoptosis dan Nekrosis}

Pengukuran apoptosis pada kultur sel endotel dilakukan berdasarkan banyaknya fragmenfragmen DNA yang dilabel BrdU pada sitoplasma (lisat), sedangkan pengukuran nekrosis dilakukan berdasarkan banyaknya fragmen-fragmen DNA yang dilabel $B r d U$ pada supernatan. Deteksi fragmen-fragmen DNA baik pada apoptosis maupun pada nekrosis menggunakan metode ELISA kit yang dibaca oleh ELISA reader pada $\lambda$ $450 \mathrm{~nm}$ pada masing-masing perlakuan kultur sel endotel dengan adanya subtrate solution (TMB). Penggunaan metode ELISA kit ini karena dianggap lebih sensitif sehingga hasil yang didapatkan lebih akurat, dan dapat digunakan pada sampel dalam jumlah yang banyak. Sedangkan $\lambda 450 \mathrm{~nm}$ menunjukkan banyak sedikitnya fragmen-fragmen DNA yang dilabel BrdU pada sitoplasma (apoptosis) dan fragmenfragmen DNA yang dilabel BrdU pada supernatan (nekrosis). Semakin tinggi nilai absorbansinya menunjukkan semakin banyak DNA yang terlabel BrdU. Untuk apoptosis, hal ini menunjukkan bahwa semakin banyak sel yang mengalami apoptosis. Demikian juga halnya pada nekrosis 
menunjukkan bahwa semakin banyak sel yang mengalami nekrosis.

BrdU merupakan analog thymidine yang sering digunakan dalam studi proliferasi sel. Dalam kultur, BrdU biasanya melakukan korporasi dengan DNA selama sintesis DNA [37]. Adapun tahapan pelabelan dan deteksi BrdU (Gambar 9) yaitu (1) MP dicoated dengan antibodi Anti-DNA, kemudian (2 dan 3) Antibodi Anti-DNA yang telah berikatan dengan MP menangkap fragmen-fragmen DNA yang dilabel $B r d U$ yang sudah didenaturasi dengan microwave irradiation. Selanjutnya (4) fragmen-fragmen DNA yang diberi label BrdU dideteksi dengan antibodi Anti-BrdU-POD conjugate (anti-BrdU yang dikonjugasikan dengan POD), yang kemudian divisualisasikan dengan menambahkan subtrate solution (TMB) untuk menghasilkan warna [38].

Berdasarkan hasil penelitian, rata-rata fragmen-fragmen DNA setiap perlakuan yang dilabel $B r d U$ pada sitoplasma (apoptosis) dan supernatan (nekrosis) ditampilkan pada Tabel 3. Dari hasil pengukuran diketahui bahwa pada kultur sel endotel normal (tanpa induksi leptin dan puerarin), leptin $25 \mathrm{ng} \mathrm{ml}^{-1}$, dan puerarin 5, 25, 200 dan $525 \mu \mathrm{M}$ tanpa leptin, serta leptin 25 ng $\mathrm{ml}^{-1}$ dan puerarin 5, 25, 200 dan $525 \mu \mathrm{M}$, ratarata fragmen-fragmen DNA yang dilabel $B r d U$ pada sitoplasma (apoptosis) (Gambar 9 A) secara berurutan masing-masing adalah 1,600 $\pm 0,290$; $1,175 \pm 0,112 ; 1,155 \pm 0,147 ; 1,275 \pm 0,233$; $1,222 \pm 0,221 ; 1,343 \pm 0,064 ; 1,065 \pm 0,111$; $1,124 \pm 0,145 ; 1,359 \pm 0,579$ dan $1,757 \pm 0,255$. Sedangkan rata-rata fragmen-fragmen DNA yang dilabel BrdU pada supernatan (nekrosis) (Gambar 9 B) secara berurutan masing-masing adalah $2,155 \pm 0,466 ; 2,077 \pm 0,189 ; 1,920 \pm 0,131$; $1,876 \pm 0,426 ; 1,529 \pm 0,299 ; 2,264 \pm 0,610$; $1,678 \pm 0,292 ; 1,526 \pm 0,173 ; 1,857 \pm 0,597$ dan $1,863 \pm 0,307$. Hasil uji statistik menunjukkan bahwa leptin $25 \mathrm{ng} \mathrm{ml}^{-1}$, dan puerarin 5, 25, 200 dan $525 \mu \mathrm{M}$ tanpa leptin, serta leptin $25 \mathrm{ng} \mathrm{ml}^{-1}$ dan puerarin 5, 25, 200 dan $525 \mu \mathrm{M}$ tidak berpengaruh signifikan $(p>0,05)$ terhadap apoptosis dan nekrosis. Hal ini menunjukkan bahwa peningkatan konsentrasi puerarin tidak berpengaruh terhadap apoptosis dan nekrosis pada kultur sel endotel yang diinduksi leptin $25 \mathrm{ng} \mathrm{ml}^{-}$ 1. Hal ini dikarenakan pada awal kultur sel endotel densitas selnya sudah tinggi, dan terjadi kematian sel secara spontan karena secara fisiologis sel endotel memerlukan ruang untuk hidupnya. Menurut Yasaka et al., densitas sel yang tinggi dapat menyebabkan kematian sel (apoptosis) [39], dan didukung oleh Roche Applied Science, bahwa semakin tinggi kepadatan sel, maka sel akan lebih cenderung mengalami apoptosis dibandingkan dengan nekrosis [38]. Selain densitas selnya yang tinggi, juga dipengaruhi oleh ROS akibat induksi leptin. Penelitian sebelumnya menyatakan bahwa pada mekanisme intraseluler, leptin dapat menginduksi apoptosis [40, 41], dan didukung oleh Bouloumie et al., bahwa sel endotel (HUVECS) yang distimulasi dengan leptin akan meningkatkan akumulasi ROS intraseluler [13], serta Artwohl et al., bahwa leptin juga mentrigger apoptosis pada jaringan lemak vaskulatur [42].

Mekanisme intraseluler leptin pada sel endotel dalam menginduksi apoptosis adalah dengan meningkatkan akumulasi ROS yang merupakan radikal bebas. Leptin berikatan dengan reseptor leptin (Ob-Rb) pada sel, kemudian leptin meng-aktivasi AMPK yang merupakan enzim fuel sensing yang akan teraktivasi apabila terjadi peningkatan rasio AMP/ATP. Fosforilasi AMPK mengaktivasi fosforilasi ACC (Acetyl-CoA Carboxylase) dan kemudian mengaktivasi Acetyl-CoA. Acetyl-CoA selanjutnya menghambat sintesis Malonyl-CoA, mengaktifkan CPT 1 (Carnitine Palmitolytransferase 1 yang merupakan enzim kunci dalam oksidasi asam lemak). Hal ini mengakibatkan peningkatan oksidasi asam lemak di mitokondria sehingga meningkatkan produksi ROS berupa radikal mitokondrial, akibatnya terjadi kondisi stress oksidatif $[43,44]$, akumulasi ROS pada selsel endotel sebagai akibat dari induksi leptin tersebut mengakibatkan terjadinya kondisi stress oksidatif, yang akhirnya dapat menyebabkan kematian sel (apoptosis atau nekrosis) secara langsung [44, 45]. Tetapi dengan adanya puerarin yang berperan sebagai antioksidan dapat menekan kematian sel akibat induksi leptin tersebut. Menurut Winarsi, reaktivitas oksidan (ROS) dapat dihambat dengan puerarin (antioksidan) dengan cara ketika isoflavon berinteraksi dengan senyawa oksidan, maka senyawa isoflavon memberikan satu gugus $\mathrm{H}$ kepada senyawa oksidan. Sehingga seketika itu juga, senyawa isoflavon berubah menjadi radikal isoflavon, sementara senyawa oksidan menjadi senyawa yang stabil. Meskipun isoflavon berubah menjadi senyawa radikal, namun senyawa tersebut tidak memiliki potensi untuk melakukan propagasi [46]. Radikal tersebut akan di nonaktifkan oleh senyawa radikal lain, sehingga 
kembali menjadi senyawa stabil. Menurut Xiong et al., puerarin dapat mencegah ROS sehingga menekan apoptosis [47], dan didukung juga oleh Nijveldt, bahwa flavonoid bertindak sebagai antioksidan untuk mencegah kerusakan yang disebabkan oleh radikal bebas dengan penangkapan oksidan secara langsung (direct scavenging) [34]. Disatu sisi akibat dari induksi leptin yang dapat menyebabkan peningkatan kematian sel, dan disisi lain puerarin yang berperan sebagai scavenger yang dapat menurunkan kematian sel, sehingga interaksi antara dua faktor tersebut pada semua perlakuan (leptin $25 \mathrm{ng} \mathrm{ml}^{-1}$, dan puerarin 5, 25, 200 dan $525 \mu \mathrm{M}$ tanpa leptin, serta leptin $25 \mathrm{ng}$ $\mathrm{ml}^{-1}$ dan puerarin 5, 25, 200 dan $525 \mu \mathrm{M}$ ) pengaruhnya tidak berbeda nyata $(p>0,05)$. Selain itu, puerarin akan memberikan efek apabila diinduksi bersamaan dengan leptin dalam waktu lebih dari 6 jam. Menurut Semetisari, puerarin dengan konsentrasi $200 \mu \mathrm{M}$ yang diinduksi bersamaan dengan leptin $25 \mathrm{ng} \mathrm{ml}^{-1}$ selama 12 jam akan memberikan efek dalam menurunkan konsentrasi TNF- $\alpha$ (Tumor Necrosis Factor- $\alpha$ ) pada kultur HUVECs secara signifikan [48], penelitian sebelumnya menyebutkan bahwa puerarin dengan konsentrasi $200 \mu \mathrm{M}$ yang diinduksi ber-samaan dengan leptin $25 \mathrm{ng} \mathrm{ml}^{-1}$ selama 12 jam juga menurunkan kadar $\mathrm{H}_{2} \mathrm{O}_{2}$ pada kultur HUVECs secara siginifikan.

Pada gambar 4.2.A dan B menunjukkan bahwa kultur sel endotel lebih cenderung mengalami nekrosis daripada apoptosis karena rata-rata fragmen-fragmen DNA yang dilabel $B r d U$ pada supernatan (nekrosis) yang terukur lebih tinggi dibandingkan dengan fragmenfragmen DNA yang dilabel BrdU pada sitoplasma (apoptosis). Hal ini dikarenakan jumlah sel yang terlalu banyak (overloading diatas rata-rata) dan kekurangan medium sebagai sumber energi (ATP) sehingga sel lebih cenderung mengalami nekrosis daripada apoptosis. Menurut Tsujimoto, nekrosis merupa-kan kematian sel yang tidak membutuhkan ATP (Gambar 9), yang ditandai dengan adanya pembengkakan pada mitokondria dan retikulum endoplasma yang menyebabkan volume sel bertambah sehingga terjadi kerusakan fungsi plasma membran [49] dan akhirnya sel mengalami lisis [50]. Kematian sel pada apoptosis merupakan mekanisme proses aktif yang membutuhkan energi (ATP), dimana sel itu sendiri aktif dalam proses destruksi. Apoptosis disebut sebagai kematian sel yang terprogram dan merupakan suatu bentuk fisiologi normal yang memegang peranan penting dalam homeostasis jaringan dewasa dan perkembangan embrio. Kematian sel pada apoptosis secara umum ditandai dengan terjadinya kondensasi kromatin, fragmentasi DNA dan pembentukan badan apoptotik (apoptotic bodies), yang akhirnya difagositosis oleh sel-sel didekatnya [49].

\section{KESIMPULAN}

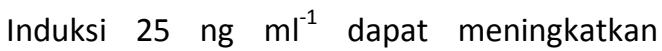
ekspresi VCAM-1 $(2,68 \pm 0,15) \%$ dibandingkan dengan perlakuan $0 \mathrm{ng} \mathrm{ml^{-1 }}(0,54 \pm 0,15) \%$. Perlakuan induksi puerarin 5, 25, 200, $525 \mu \mathrm{M}$ memberikan dampak negatif terhadap ekspresi VCAM-1 meskipun pengaruh ini tidak signifikan. Puerarin dapat menekan apoptosis dan nekrosis sel, $525 \mu \mathrm{M}$ puerarin secara efektif dapat menekan ekspresi PPAR- $\gamma$. Puerarin tidak memberikan dampak yang signifikan terhadap aktivitas ekstraseluler berdasarkan hasil analisis aktivitas SOD dan $\mathrm{H}_{2} \mathrm{O}_{2}$.

\section{DAFTAR PUSTAKA}

1. Vander, A., J. Sherman., D. Luciano. 2001. Human Physiology: The Mecanisms of Body Function. McGraw-Hill Higher Education. New York.

2. Lau, D. C W., B. Dhillon., H. Yang., P. E. Szmitko., S. Verma. 2004. Adipokines: Molecular Links Between Obesity and Atheroslcerosis. University of Toronto. Canada.

3. Libby, P., P. M. Ridker., A. Maseri. 2002. Inflammation and Aterosklerosis. Circulation. 105:1135-1143.

4. Ross, R. 1999. Aterosklerosis-An Inflammatory Disease. N Engl J Medd. 340:115-126.

5. Singh, P., M. Hoffmann., R. Wolk., Shamsuzzaman, S.M. Abbu., K. V. Somers. 2007._Leptin Induces C-Reactive Protein Expression in Vascular Endothelial Cells. American Heart Association, Inc. New York.

6. Kawanami D., K. Maemura., N. Takeda., T. Harada., T. Nojiri., T. Saito., I. Manabe., Y. Imae., R. Nagai. 2007. C-reactive protein induces VCAM-1 gene expression through NFkappaB activation in vascular endothelial cells. University of Tokyo. Japan.

7. Liang Y.J., K.G. Shyu ., BW. Wang ., LP. Lai . 2007. C-reactive protein activates the nuclear factor-kappaB pathway and induces vascular cell adhesion molecule-1 expression through CD32 in human umbilical vein endothelial cells and aortic endothelial cells. National Taiwan University. Taiwan. 
8. Hill, J. O., H. R. Wyatt., G. W. Reed., J. S. Peters. 2003. Obesity and The Environment: where do we go from here?. Science. 299:853-855.

9. Born V. dan J. Schwartz. 1997. Vascular Endothel Physiology, Pathology and Therapeutic Oppurtunities. Schattauer. Stuttgart. Berlin.

10. Marks, D.S., J. A. Vita., J. F. Keuney., G. N. Welch., J. Loscalzo. 1995. Inhibition of Neointimal Proliferation in Rabbit Following Vascular Injury by a Single Treatment With a Protein Adduct of Nitric Oxide. J. Clin Invest. 96:2630.

11. Sanyin, Z., C. Shilin., S. Yingjun., Y. Dajian., L. Xijing., S. Albert., X. Hongxi. 2007. Puerarin Induces Angiogenesis in Myocardium of Rat with Myocardial Infarction(Pharmacology). National Institute of Informatic. Japan.

12. Khotimah, H. 2003. Keterkaitan Pengaruh Pemberian Vitamin E dan C Terhadap Bioavaibilitas Endothelial-Derived Nitric Oxide (EDNO), Malondealdehide (MDA) dan Kepadatan Sel Endotel Kultur HUVECs Kondisi Glukosa Tinggi. Program Pascasarjana Universitas Brawijaya. Malang.

13. Boulomie, A., T. Marumo., M. Lafontan., R. Busse.1999. Leptin Induce Oxidative Stress in Human Endotelial Cells. The FASEB Journal Vol 13.hal:1231-1237.

14. Brian R., BR. Clapp., GM.Hirschfield. 2005. Inflammation and Endothelial Function Direct Vascular Effects of Human C-Reactive Protein on Nitric Oxide Bioavailability. Circulation. 111:530-1536.

15. Lawrence, G. S. 2007. Implikasi Klinis Disfungsi Endotel dan Radikal Bebas. Universitas Hasanudin. Makasar.

16. Ding, M.P., F. Feng, H.T. Hu. 2007. Effects of puerarin on expression of nuclear factor kappaB after cerebral ischemia/reperfusion in rats. Zhongguo Zhong Yao Za Zhi. Dec. 32. 23:2515-2518.

17. Lodish, H., A. Berk, S. L. Zipursky, P. Matsudaira, J. Darnell. 2003. Molecular Cell Biology. $5^{\text {th }}$ Edition. W.H. Freeman and Company. New York.

18. Prasain, J.K., K. Jones, N. Brissie, D.R. Moore, J.M. Wyss, S. Barnes. 2004. Identification of puerarin and its metabolites in rats by liquid chromatography-tandem mass spectrometry. Journal of Agricultural Food Chemistry. 52:3708-3712.

19. Sun, X.H., J.P. Ding, H. Li, N. Pan, L. Gan, X.L. Yang, H.B. Xu. 2007. Activation of Large-
Conductance Calcium-Activated Potassium Channels by Puerarin: The Underlying Mechanism of Puerarin-Mediated Vasodilation. JPET. October. 323. 1:391-397.

20. Dadogo Jack S, Fanelli C, Paramore D, Brothers dan J, Landt M. 1996. Plasma leptin and insulin relationships in obese and non obese humans. Diabetes. 45:695-698.

21. Delerive P., Martin-Nizard F., Chinetti G., Trottein F., Fruchart JC., Najib J., Duriez P dan Staels B. 1999. Peroxisome proliferatoractivated receptor activators inhibit thrombin-induced endothelin-1 production. Circ Res. Sep 3. 85. 5:394-402.

22. Mdidea. 2007. What is Pueraria root (kudzu root)? Value of Pueraria root (kudzu root) and Pueraria root (kudzu root) extracts?. http://www.mdidea.com/.../herbextract/kudz u/data.html. Tanggal akses 12 Juni 2007.

23. Jia G.F., H.M. Xie. 1999. New Usage of Clinical Medicine. $1^{\text {st }}$ ed. People's Health Publishing House. Beijing.

24. Cimino, F., F. Esposito, R. Ammendola, T. Russo. 1997. Gene regulation by reactive oxygen species. Curr. Top. Cell. Regul. 35:123147.

25. Pulverer, B. J., Kyriakis, J. M., Avruch, J., Nikolakaki, E., dan Woodgett, J. R. 1991. Phosphorylation of c-jun mediated by MAP kinases. Nature (London). 353:670-674.

26. Weaves, R.F. 2003. Molecular Biology, second edition. Mc-Graw Hill Companies, Inc. New York.

27. Banks A.S., S.M. Davis, S.H. Bates, M.G.Jr. Myers. 2000. Activation of downstream signals by the long form of the leptin receptor. J Biol Chem. 275:14563-14572.

28. Grayck, E.N., C.S. Dieterle., C.A. Piantadosi., J.J. Enghild., T.D. Oury. 2000. Secretion of extracellular superoksida dismutase in neonatal lungs. Am J Physiol Lung Cell Mol Physiol. 279:977-984

29. Brooks, P.S., Y. Yoon., J.L Robotham., M.W. Anders., S.S. Sheu. 2004. Calcium, ATP, and ROS : a itochondroal love-hate triangle. Am J Physiol Cell Physiol. 287:C817-C833.

30. Yamagishi, S., D. Edelstein, X.L. Du, Y. Kaneda, M. Guzmán, M. Brownlee. 2001. Leptin induces mitochondrial superoxide production and monocyte chemoattractant protein-1 expression in aortic endothelial cells by increasing fatty acid oxidation via protein kinase A. Department of Medicine, Diabetes Research Center, Albert Einstein College of 
Medicine,Bronx. www.jbc.org. Tanggal 6 Agustus 2007

31. Hayden, M.R., S.C. Tyagi. 2002. Intimal Redox Stress: Accelerated Aterosklerosis in Metabolic Syndrome and Type 2 Diabetes Mellitus. Atheroscleropathy. Cardiab. 1:1- 27.

32. Nijveldt R. J., Els van Nood, D.E.C. van Hoorn, P.G. Boelens, K. van Norren, P.A.M. van Leeuwen. 2001. Flavonoids: a review of probable mechanisms of action and potential applications. American Society for Clinical Nutritions. 74:418-425.

33. Korkina L.G., I.B. Afanas'ev. 1997. Antioxidant and chelating properties of flavonoids. Adv Pharmacol. 38:151-163.

34. Hancock, J.T., R. Desikan, S.J. Neill. 2001. Role of reactive oxygen species in cell signaling pathways. J. Biochemical Society Transactions. Vol29. part 2.

35. Zmijewski, J.W., A. Landar, N. Wanatabe, D.A Dickinson, N. Noguchi, V.M Darler-Usmr. 2005. Cell signaling by oxidized lipids and the role of reactive oxygen species in the endothelium. Biochemical Society Transactions. Vol 33, part 6.

36. Gordon, M.H. 1990. The mechanism of antioxidants action in vitro. dalam B.J.F. Hudson, editor. Food Antioxidants. Elsivier Applied Science. London.

37. Biocompare. 2009. BrdU In-Situ Detection Kit From BD Biosciences. Biocompare.

38. Roche Applied Science. 2005. Cellular DNA Fragmentation ELISA. Cat. No. 1585045. Instruction Manual. Version August 2005.

39. Yasaka, T., S. Ichisaka., T. Katsumoto., H. Maki., M. Saji., G. Kimura., dan K. Ohno. 1996. Apoptosis Involved in Density-dependent Regulation of Rat Fibroblastic 3Y1 Cell Culture. Cell Structure and Function. 21: 483489.

40. Qian, H., G. J. Hausman., M. M. Compton., M. J. Azain., D. L. Hartzel, C. A. Baile. 1998. Leptin Regulation of Peroxisome ProliferatorActivated Receptor-Gamma, Tumor Necrosis Factor, and Uncoupling Protein-2 Expression in Adipose Tissues. Biochem and Biophys Res Commun. 246:660-667.

41. Qian, H., M. J. Azain., M. M. Compton., D. L. Hartzel., G. J. Hausman, C. A. Baile. 1998. Brain Adminstration of Leptin causes Deletion of Adipocytes by Apoptosis. Endocrinology. 139:791-794.

42. Artwohl M., M. Roden., H. Hölzenbein., A. Freudenthaler., W. WaldhäusI, S.M.
Baumgartner-Parzer. 2002. Modulation by Leptin of Proliferation and Apoptosis in Vascular Endothelial Cells. International Journal of Obesity. 26:577-580.

43. Minokoshi $Y$ and B. B. Kahn. 2003. Role of AMP-Activated Protein Kinase in LeptinInduced Fatty Acid Oxidation in Muscle. Biochemical Society Transactions. 31. 1:196201

44. Lum, H. dan K. A. Roebuck. 2001. Oxidant Stress and Endothelial Cell dysfunction. Am. J. Physiol Cell Physiol. 280:C719-C741.

45. Halliwell, B., J. M. C. Gutteridge. 1996. Antioxidant In Nutrition, Health and Disease. Oxford University Press Inc. New York

46. Winarsi, H. 2005. Isoflavon. Gadjah Mada University Press. Yogyakarta.

47. Xiong, F. L., X. H. Sun., L. Gan., X. L. Yang, H. B. Xu. 2006. Puerarin Protects Rat Pancreatic Islets from Damage by Hydrogen Peroxide. Eur J Pharmacol. 529:1-7.

48. Semetisari, R. 2008. Studi Efek Puerarin Dalam Menurunkan Konsentrasi Tumor Necrosis Factor- $\alpha$ (TNF- $\alpha$ ) Pada Kultur Human Umbilical Vein Endothelial Cells (HUVECs) Yang Diinduksi Leptin. Skripsi. Jurusan Biologi. Fakultas Matematika dan Ilmu Pengetahuan Alam. Universitas Brawijaya. Malang.

49. Tsujimoto, Y. 1997. Apoptosis and Necrosis: Intracellular ATP Level as A Determinant for Cell Death Modes. Cell Death and Differentiation. 4:429-434.

50. Bezvenyuk, Z. 2001. Multiple Pathways of DNA Disintegration During Neuronal Apoptosis. Department of Neuroscience and Neurology. Series of Reports. No 56:1-59. 